\title{
Teaching Engineering and Food: From Traditional Approaches to a Flipped Course on Gastronomic Engineering
}

\author{
José M. Aguilera ${ }^{1}$ M. Carolina Moreno ${ }^{1}$
}

Received: 26 September 2020 / Accepted: 9 February 2021 / Published online: 11 March 2021

(c) The Author(s), under exclusive licence to Springer Science+Business Media, LLC part of Springer Nature 2021

\begin{abstract}
Understanding concepts of food engineering (FE) is fundamental for professionals in the discipline, necessary for food scientists, appealing to non-food science students, and valuable for curious cooks. The challenge of teaching FE is delivering meaningful learning outcomes to the different backgrounds, motivations, and interests of the audiences. This article delves into the origins of FE in academia and the influence on teaching of an expanding food processing industry. Current trends demand a FE education with a wider scope, focused on consumer needs and wants that convey elements of food product design, sustainability, innovation, and culinary applications, among others. Although the core concepts of FE have remained practically the same, new teaching methodologies call for expanded computational abilities, ample access to online contents, and active learning, student-centered approaches. As a case study, we describe the implementation of an elective flipped classroom course on engineering, science, and gastronomy for undergraduate students that include in-class demonstrations by chefs.
\end{abstract}

Keywords Food engineering · Food product engineering $\cdot$ Gastronomic engineering $\cdot$ Undergraduate education $\cdot$ Teaching methodologies $\cdot$ Flipped learning

\section{Introduction}

Food engineering (FE) emerged in academia in the 1950s as a disciplinary field related to food manufacturing $[1,2,3]$. The original focus of FE was "to advance the implementation of efficient industrial processing in the transformation of raw materials of biological origin into edible forms" [4]. FE evolved to serve a processing industry keen on increasing throughput and reducing costs [5]. In academia, FE pioneered among engineering sciences in applying mass and energy balances, transport phenomena, and chemical reaction kinetics to structured materials of biological origin [6,7]. Several universities around the world started research and education in FE with the concomitant emergence of undergraduate and graduate programs, courses, and academic degrees, as well as specialized textbooks, conferences, and journals on the

José M. Aguilera

jmaguile@ing.puc.cl

1 Department of Chemical and Bioprocess Engineering, Pontificia Universidad Católica de Chile, Vicuña Mackenna 4860, Santiago, Chile subject $[1,8]$. FE education has become an obliged theme of discussion at conferences, such as ICEF (International Congress on Engineering and Food), CIBIA (Ibero American Congress of Food Engineering), the annual meeting of IFT (Institute of Food Technologists), and CoFE (Conference of Food Engineering) as well as in food science and technology (FS\&T) meetings in different countries.

However, since the beginnings of this century, FE in academia faces diminishing funding for research, dwindling critical masses in faculties (particularly at universities in the USA) and decreasing student enrollment [9]. Some scholars argue that FE is at crossroads and needs to reassess its vision and expand the scope to grand societal drivers such as health and wellness, food inside our bodies, food security and safety, population growth and aging, water and land shortage, and environmental concerns [9]. Others add that FE should integrate stakeholders outside the food manufacturing industry like the food service industry, innovative small and medium enterprises (SMEs), and the world of gastronomy [10, 11]. Members of the FE and FS\&T professions request 
a broader and more applied education that offers better opportunities for entrepreneurship [12].

Foods are familiar objects to teach science and engineering [13, 14, 15]. Heat, mass, and momentum transfer take place not only in large-scale food processing operations but also during cooking in the kitchen, inside foods, and even during digestion [16, 13, 17]. Simple experiments carried out with foods can explain most basic concepts of physics, biophysics, physical chemistry, thermodynamics, and materials science $[18,19,20]$. This article reviews the characteristics of several FE programs and courses and discusses current trends in teaching approaches to communicate FE concepts to several audiences. It also describes the case of a flipped class course on gastronomic engineering that imparts concepts of physical sciences and food engineering using examples from the practice of culinary art.

\section{Current Trends}

\section{Global Trends in Alimentation and FE Education}

The next decades will witness important changes in alimentation, namely, in the integrated view of human, technological, sociocultural, and environmental issues behind what, how, and with whom we eat [21]. These changes may affect FE, and in particular, FE education as discussed by Boom and Janssen [22], Niranjan [11], Roos et al. [23], and Saguy et al. [9]. Three global tendencies are particularly relevant to the contents of this review.

- Unprecedented technology changes are foreseen in the use of scarce resources (e.g., land, fresh water and energy), the impact of food processing/distribution on the environment (e.g., GHGs, effluents, waste packaging), and the processing of foods for a health conscious but apprehensive consumer [24, 25].

- Changing lifestyles and demographics that lead to less food preparation at home, new eating habits, and food products for particular diets. This trend brings food technology closer to institutional and personalized alimentations and a safe delivery of meals [18]. In turn, a rising aging population requires food products and meals tailored to needs imposed by physiological and nutritional conditions [26].

- The ubiquitous presence of information and communication technologies (ICT) in the form of computers, tablets, and cell phones with the concomitant access to a wealth of information in the Internet in the form of videos, open classes and courses, scientific papers, etc.

\section{Trends in the Practice of Engineering Education}

This scenario necessarily calls for a change in the paradigm of a traditional FE education centered in the food manufacturing industry. The new vision should deploy concepts of FE in the context of sustainable food processes, products for changing lifestyles and beliefs, innovation for health and well-being, and novel methodologies that suit audiences of the digital age. In the case of Europe, Roos et al. [23] propose introducing courses and programs covering entrepreneurship and innovation, promoting novel teaching methods for a new generation of students, and enforcing quality educational standards and certification.

Engineering education is experiencing dramatic changes. The traditional teaching model where students have a passive presence in the lecture room is giving way to more active, student-centered and participatory approaches. Active learning in engineering facilitates acquiring foundational knowledge as well as soft skills such as teamwork, problemsolving abilities, and entrepreneurial mindsets [27]. It also encourages utilization of digital technologies such as simulation software and virtual laboratories (García-Peñalvo and Colomo-Palacio [28]). Among novel methodologies suggested for engineering education are project-based learning, hybrid-learning, the flipped classroom, and design thinking [29, 30, 31]. New platforms, such as Massive Open Online Courses (MOOCs), webinars, blogs, Facebook, Instagram, and Twitter, among others, have opened up new spaces for disemination of ideas, experiences, and training in food related matters [32]. Online and open learning permits access anytime and anywhere to formal classes, teaching modules on specific topics and informal discussion sites, thus effectively democratizing learning, the dissemination of knowledge to vast audiences, and coping with the educational demands in times of the Covid-19 pandemia [33].

\section{Teaching Food Engineering}

\section{Food Engineering Programs Around the World}

Education in FE is formally deployed worldwide through programs that have different origins, academic affiliations, and scopes. In the USA, most FE departments and programs emerged in Colleges or Schools of Agriculture while in Europe (Germany in particular); they originated as branches of process engineering or chemical and mechanical engineering [3]. FE programs in the USA are not affiliated with Colleges of Engineering, possibly because a FE curriculum has to trade off some fundamentals in engineering for basic science courses 
(e.g., microbiology, biochemistry) and several food science and technology subjects considered applied science. This imbrication of FE and FS\&T becomes quite clear after revising the research areas of some food engineers at universities and the topics covered in articles of FE journals and presented at FE conferences (see [34]. Today, FE groups in academia are largely associated with departments of FS\&T (often Nutrition and FS\&T), which limits the access to students with adequate skills in math and physics and often lessens the quality of the engineering material taught [9]. In general, most academic programs in FE are built around a foundation of basic science courses and bridged to a core of engineering courses by a set of intermediate enabling subjects. A possible grouping of topics that constitute the heart of a FE curriculum is presented in Fig. 1.

It is difficult to estimate the number of FE programs around the world. Roos et al. [23] asserted that in Europe, there were around 400 bachelor and master programs that demanded the study of FE to different extents and depths. Of the $70 \mathrm{PhD}$ programs in FS\&T, only a few offered a $\mathrm{PhD}$ in FE. The ISEKI database on academic curricula lists $34 \mathrm{BSc}, 14 \mathrm{MSc}$, and $4 \mathrm{PhD}$ programs in Europe whose names explicitly refer to "food engineering" or "agrifood engineering" (https://www.iseki-food.net/curricula?title= food+engineering \&field_curr_degree_value $=$ All $\&$ country $=$ All)By the year 2000, Latin American universities boasted over 100 undergraduate programs in FE, but this information is not updated [37]. Brazil alone reports 96 undergraduate bachelor degree programs in $\mathrm{FE}$, equivalent to 7000 admissions per year [38]. There are at least 50 Departments of Food Engineering in Turkey that graduate around 1000 students per year [39]. The popularity of FE programs in emerging countries is due to a real demand for specialized human resources and the prestige bestowed by a degree in"engineering." A search in the Food Science and Technology database with the words food, engineering, and education (accessed on August 26, 2020) resulted in a large number of articles related to FE teaching practices and innovations in China in the last 4 years, but no information on number of FE programs or their contents.

Understanding concepts of FE is fundamental for professionals in the discipline, necessary for food scientists, exciting for non-science students, and valuable in the culinary arts and for curious professional cooks and people interested gastronomy. In this respect, the contents and delivery options of FE material have to match the learning outcomes expected by audiences with different backgrounds and interests. In academia, the quantity and scope of some FE-related programs have expanded to accomodate an interdisciplinary vision that brings in aspects of innovation, sustainability, consumer sciences, and gastronomy [40, 41, 42]. Besides, employers in the food and restaurant sectors are demanding a formation in "soft skills" that encourages communication abilities, critical thinking, problem-solving capacities, and working in groups [36, 23]. For the analysis, the ample spectra of audiences and learning objectives in teaching FE were divided into four major groups Fig. 2: food engineering majors, food science/food technology students, non-food science undergraduates, and students in Culinary Arts, and Hospitality Management and chefs. Figure 2 also highlights some educational tools (e.g., problem-solving software and computer simulation, pilot plant experiences, culinary practices) that may be used depending on the different practical orientations of students.
Fig. 1 Concise list of main topics in a food engineering program. Suggested new subjects are in italics. Sources: Barron [35], Boom and Janssen [22], Flynn et al. [36], Niranjan [11]
Basic science foundation

Math, physics, biology, microbiology, chemistry, biochemistry

\section{Supporting subjects} Thermodynamics, physical chemistry, fluid mechanics, computer science, economics

\begin{tabular}{|l|}
\multicolumn{1}{|c|}{$\begin{array}{c}\text { Complementary } \\
\text { knowledge/skills }\end{array}$} \\
Communications, health \\
and nutrition, environmental \\
sustainability, consumer \\
preferences and sensory \\
science, gastronomy, food \\
innovation and marketing \\
\hline
\end{tabular}

Core food engineering Mass and energy balances, transport phenomena, heat and mass transfer, unit operations, process control, food materials science, food plant design and costing, food product design. Other engineering courses (mechanical, electrical)

\begin{tabular}{|} 
Food science and \\
food technology \\
Food chemistry, food \\
microbiology, food \\
technology and \\
processing, product \\
development
\end{tabular}




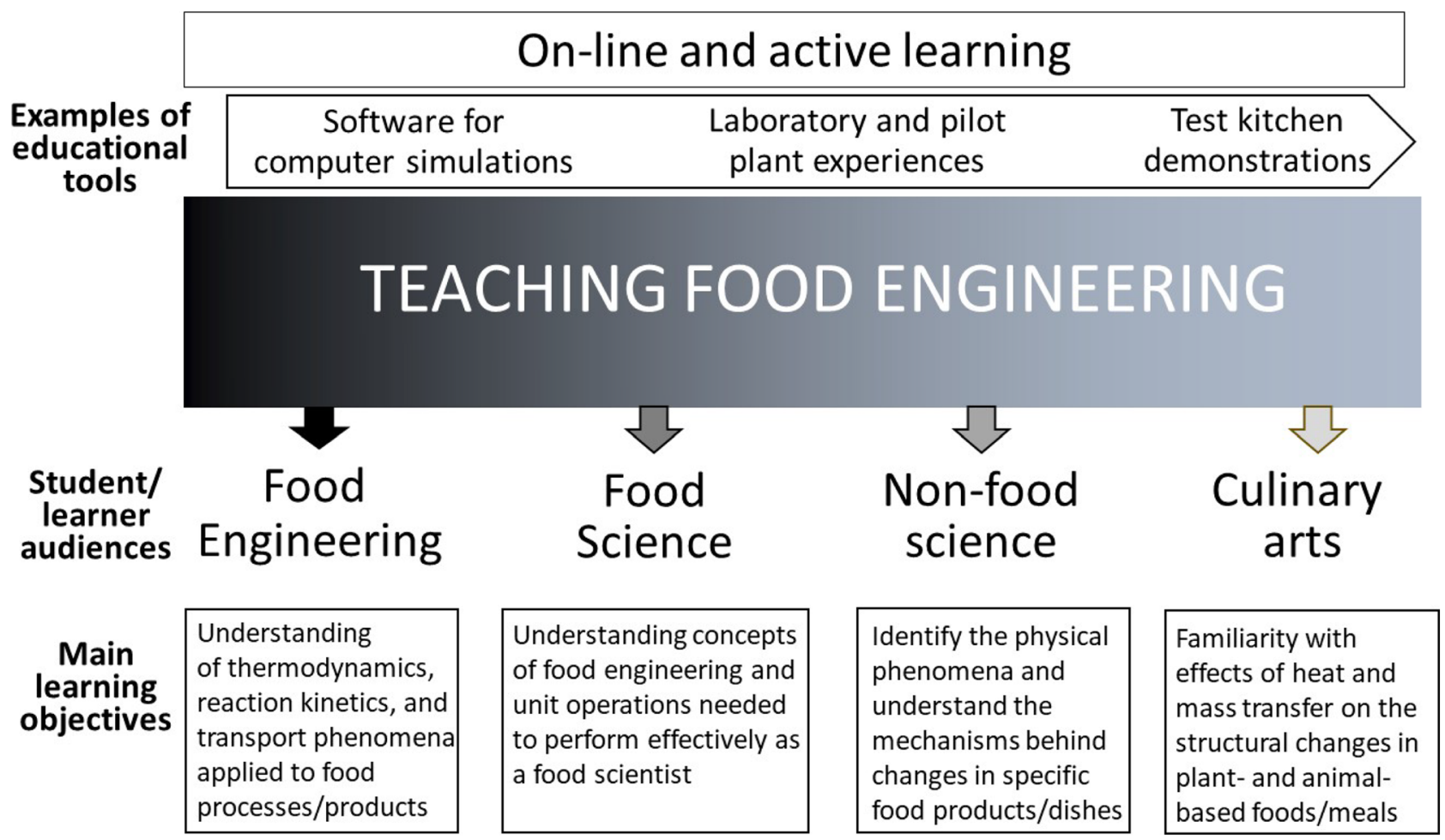

Fig. 2 Scope of target audiences for programs teaching concepts of food engineering and desirable learning outcomes

\section{Food Engineering Majors and Graduate Students}

There are undergraduate and graduate programs leading to specific degrees on engineering and foods. This is the case of traditional Food Engineering and Agricultural Engineering programs and also emerging engineering fields that include "Biological" and "Biological Systems" in their names [43]. As part of their FE formation, food engineers must be proficient in principles of thermodynamics and fluid mechanics as well as heat, mass, and momentum transfer and their applications to unit operations relevant to food processing and packaging Fig. 1. As deducted from a worldwide survey conducted by Saguy and Cohen [12], most FE graduates work in food processing, product development and formulation, quality control, applied research, and equipment design.

Saguy et al. [9] suggested that textbooks on FE are objective and available sources of information to trace some of the main milestones in the evolution of $\mathrm{FE}$ education. The 3-volume Elements of Food Engineering, by Parker et al. [44], is often cited as the first textbook on FE published in English [1]. The book was “...focused on the descriptive aspects of processing technologies employed in the food industry" [9]. However, it appears that courses related to dairy engineering existed as early as the $1920 \mathrm{~s}$, probably of the same nature as Parker's book [45]. Kostaropoulos [3] reminds that in 1948, Prof.
J. Kuprianoff at the Technical University of Karlsruhe (Germany) introduced FE under the denomination of Food Process Engineering (Lebensmittel Verfahrenstechnik). Kuprianoff, later appointed to the Chair of Food Processing Technology in 1964 and held this position until his death in 1971. Prof. R. Plank, his predecessor at TU Karlsruhe from 1924 to 1954 , had already initiated research in refrigeration and freezing of foods, and his equation to estimate freezing times is notable to this date [46]. In the late 1960s, Prof. M. Loncin then at University of Karlsruhe, published the influential book Fundamentals of Food Process Engineering (in German), with a strong basis in chemical engineering [47]. An abridged English version of the book became available later [48].

At MIT, the chemical engineer S.E. Charm became assistant professor of $\mathrm{FE}$ in the late 1950s and published the book Fundamentals of Food Engineering with a solid orientation towards mathematics and applied biology [49, 6]. Charm's pioneering work on the fluid flow of foods demonstrates the depth and rigor of his engineering approach [50]. Between 1960 and 1989, Prof. M. Karel expanded graduate teaching and research in food technology and FE at MIT (later at Rutgers University), pioneering in the application of physical chemistry and chemical engineering to explain food processing and preservation [51]. He and Prof. D. Lund are the authors of the acclaimed textbook Physical Principles of Food Preservation [52]. 
From the 1970s on, several FE courses started to be taught around the world by academicians with a strong background in chemical or mechanical engineering, and several texts on FE and unit operations in the food industry became available [9]. In 1984, Singh and Heldman [53] published the textbook Introduction to Food Engineering for students majoring in food science, now in its fifth edition. Most of the pioneers in FE education were recognized with the IAEF Life Achievement award in FE presented for the first time at the ICEF Meeting in Athens, Greece, in 2011 (https://www.yumpu.com/en/document/read/22456453/iaeflife-achievement-awards-presentation-11th-international).

In the past, graduate courses in FE aimed at students with a strong chemical engineering background, many of whom came from overseas. In these teacher-centered courses, students had direct contact with the instructor to perform the different tasks and most of the lecture time was devoted to chalkboard teaching of the subject matter [54]. To conform to requirements of the food industry, hands-on experience in pilot plants and internships in factories complemented $\mathrm{FE}$ courses [55, 54]. Pilot plant practices at universities were supervised by experienced faculty (most of whom are now retired), and students usually followed operating instructions from handouts to verify expected results [56], [57].

Although the core concepts of a FE course (or courses) remain practically the same, the capabilities in numerical computation (e.g., spreadsheets, MATLAB ${ }^{\mathrm{TM}}$ ) and simulation (e.g., computational fluid dynamics or CFD and ASPEN software) available to students have increased dramatically with the advent of personal computers Fig. 2. Concurrently, technology-supported classrooms and online environments permit multiple modes of interactive teaching and learning experiences [58]. Interactive software for FE calculations used as teaching and learning tools have been available for some time [59]. Problem solving by computer simulation can promote visual learning for students with limited math skills [101]. Moreover, several computer-aided software developed for food processing may partly replace or complement practical experimentation in pilot plants [60], [61], [57].

In the early 1990s, several chemical engineering departments realized a necessity to expand their focus from the processing of commodity chemicals (mostly liquids and gases) to the design of consumer products where structure imparts the desired properties and functionality [62]. In FE departments (and industry) emerged a food materials science (FMS) as an interdisciplinary field involving concepts of polymer physics, food microstructure, and macroscopic properties of foods, aimed at applications in product and process technologies [63, 64, 65, 96]. FMS became the foundation of a rational design of food products that add value by tailoring functionalities that suit specific consumer needs. In the present context, food product design should be a priority in a modern FE curriculum
$[11,23]$. A course in food product design should include a solid formation on product design methodologies and comprise the conceptualization of functional requirements, utilization of applied mathematics and principles of FMS, applications of novel technologies, and experience with hands-on products by association with industry [99, 66]. Figure 1 shows how FMS and food product design courses, as well as the subjects of sustainability and innovation, may be integrated in a FE curriculum.

There is a need for accreditation standards of quality assurance in FE education and the regulation for the practice of the profession. The American Society of Agricultural and Biological Engineering (ASABE) only accredits a few genuine FE programs in the USA and internationally (https:// www.asabe.org/Careers/Accredited-Academic-Programs-inAg-Bio-Engineering-Technology). Four EU countries regulate the professional practice of FE, and Turkey requires a degree equivalent to food engineer only for industrial operations involving large power equipment [67]. Interestingly, FE education in the UK appears to be under the tutelage of the Institution of Mechanical Engineers (https://nearyou.imeche. org/docs/volunteer-resource-centre---toolkits/careerspresentations---food-engineer-guild.pdf?sfvrsn=2).

Due to space limitation, this review cannot cover the enormous contribution of many food engineers in academia and industry to research and teaching of food processing and food technology. In fact, Misra et al. [68] rightly argue that students of FS\&T and FE do not get in their courses a motivating and inspiring exposure to the history of technological developments in the field of food processing. Their article provides a good review of the highlights of conventional thermal technologies and a good coverage of advances in emerging technologies. As depicted in Fig. 1, a dedicated and rigorous instruction in food technology and food processing is an essential complement for a quality FE education.

\section{Food Science/Food Technology Students}

Most undergraduate curricula in FS\&T require the development of competences in FE. For example, in the USA, an academic program in FS\&T to be approved by the Institute of Food Technologists (IFT) has to comply with a "standard" (formerly a core competency) in food engineering and processing. This means that students should develop knowledge or skills in thermodynamics, mass and energy balances, fluid flow, mass and heat transfer, as well as have some practical experience in unit operations in a laboratory or pilot plant [69]. This is quite an ambitious objective given that undergraduate students majoring in Chemical Engineering may study these subjects in several courses. 
Professors Singh and Heldman developed the popular textbook Introduction to Food Engineering specifically for use of undergraduate students pursuing a 4-year degree program in FS\&T [70]. A glance at the contents of the book reveals a very comprehensive and rigorous coverage of the aforementioned topics. Prof. Richard Hartel in the Foreword for this book argues "...most Food Science students would probably claim the Food Engineering course as the most difficult one in their undergraduate curriculum." He then adds, "... part of the difficulty may be related to how food engineering is taught" [71]. At least in the USA, many FS\&T students do not seem sufficiently well prepared in math and physics to handle the level of difficulty of a FE course [72]. At times when most universities are relying on online sources to assist in student learning, Professor R. Paul Singh has placed on the Internet an Introduction to Food Engineering tutorial consisting of 34 modules (videos) and 23 virtual laboratory practices [73]. A course in food processing engineering is also available in the MOOC modality (https://www.classcentral.com/course/swayamfundamentals-of-food-process-engineering-14075).

Accreditation of FS\&T programs is uncommon in the European Union. In the United Kingdom, the Institute of Food Science and Technology (IFST) provides accreditation to bachelor and master programs in FS\&T for face-to-face and distance-learning modalities. Among the basic entrance requirements are knowledge of math, physics and principles of engineering (https://www.ifst.org/organisations/accreditationschemes/accreditation-degree-courses).

\section{Non-food Science Students}

Elective courses for non-food science majors that combine physics, chemistry, biology, engineering, cooking, and gastronomy are becoming quite popular to fulfill the physical sciences and life sciences requirements of curricula [15]. An early example of such a course is Science of Food and Cooking imparted by faculty of the Department of Chemistry at the University of the South (Sewanee, TN). The focus was the understanding of scientific concepts and the application of the scientific method through experiments with foods and food preparations [74]. An iconic example of a physics/cooking course is Harvard's Science \& Cooking: From Haute Cuisine to Soft Matter Science, offered by the School of Engineering and Applied Sciences since 2008. These series of lectures introduced the novelty of bringing professional chefs into the classroom, for example, the Michelin-starred Spanish chef Ferrán Adria. In this course, Harvard professors explain and top chefs demonstrate the basic concepts in chemistry, physics, physical chemistry, and engineering behind cooking and haute cuisine (https://canvas.harvard.edu/courses/8443/assignments/ syllabus). The course offered through Harvard's edX online platform has reached over 140,000 viewers. At Wageningen
University (The Netherlands), two modules on Molecular Gastronomy integrated physics and gastronomy at the master's level, with practical assignments performed by chefs at the premises of a culinary school [75]. Science and Food: Physical and Molecular Origins of What We Eat at UCLA conveys concepts of life sciences and physical sciences in the context of food texture and flavor [76]. As described in "Case Study: a Flipped Classroom Course on Gastronomic Engineering," since 2015, we have taught the elective undergraduate course Introduction to Gastronomic Engineering that aims at providing concepts in FE and the physical sciences in the context of culinary demonstrations by chefs [77].

Although these courses are not directed to FS\&T students, they may bring a view of the food service and gastronomic sectors. Moreover, they are an opportunity for interactions with students from other disciplines, including those from the social sciences. Undergraduate programs in nutritional sciences should consider these learning experiences in FE and physics not only to comply with STEM requirements but also to facilitate later professional interactions with food technologists and food engineers [78], [79].

\section{Culinary Arts and Hospitality Management Students and Chefs}

Teaching concepts of food technology was uncommon in culinary schools. However, the expansion of the food service and institutional feeding sector has stimulated a demand for professionals knowledgeable in technology and food operations [80]. Moreover, the efficient utilization of novel gastronomic equipment such as rotary evaporators, freeze-dryers, centrifuges, and smart ovens, among others, demand operators that understand their working bases [81, 10. Some curricula for bachelor studies in culinary arts already include courses in food science and ingredient functionality and even envision partnerships with departments of science and engineering [82, 83]. The Culinary Institute of America (CIA) offers a Bachelor of Professional Studies in Culinary Science degree that lists among its contents dynamics of heat transfer, precision temperature cooking, and the physical properties of food (https://www.ciachef. edu/cia-culin ary-science-bachelors-degree-program/). The University of Massachusetts offers a 3-year food science degree for culinary arts students that includes courses in food engineering (www.umass.edu/foodsci/ undergraduate/curriculum/food-science-degree-concentrationculinary-science). Another multifaceted and mind-broadening alternative is the Master of Science in Culinary Innovation option of the European FIPDes (Food Innovation and Product Design) program that merges aspects of food innovation, molecular gastronomy, and product design with knowledge of the restaurant and hospitality industries [84]. 
A multitude of professional cooks and chefs, having great practical experience, are eager to expand their understanding of the science and engineering behind their dishes [81, 85]. Most of them realize that innovation is key to their business and the scientific method an efficient way of experimentation in their test kitchens [10]. Moreover, an engaged and productive conversation between food technologists/food engineers on issues that matter to chefs and amateur cooks needs clarity and greater precision on concepts relating culinary and scientific terms [86]. Such a lexicon may be an outcome of a module on FE dedicated to students and professionals in the gastronomy sector.

\section{Case Study: A Flipped Classroom Course on Gastronomic Engineering}

\section{Gastronomic Engineering}

Gastronomic engineering (GE) is applying the vast body of knowledge in FE and FMS to the understanding and improvement of culinary processes and dishes [77]. In short, GE deals with the physics and engineering phenomena as well as structural transformations occurring inside foods during cooking. Boom and Janssen [22] have described GE as the engineering involved in the preparation of foods for immediate consumption (i.e., right after cooking). From the $R \& D$ viewpoint, GE is an interdisciplinary space of co-creation for food engineers and chefs, and a meeting point with ideas from other disciplines (other engineering sciences, nutrition, design, anthropology, etc.). On the educational side, GE is an excellent platform to teach concepts of physical chemistry, food microstructure, properties of foods, and heat and mass transfer to undergraduate students with no or limited background in FS\&T. The familiarity of students with foods and meals and the backing of lectures with culinary demonstrations by chefs facilitate the teaching and learning experiences.

\section{A Flipped Course in Gastronomic Engineering}

Introduction to gastronomic engineering aims at providing concepts in the physical sciences and food engineering to undergraduate students by exposing them to culinary techniques and cooking [77]. Another objective is to present FE as a broad-based field, capable of multiple interactions with other disciplines (e.g., gastronomy, agriculture, food science, neurobiology and nutrition), and conducive to innovation and entrepreneurship. We adopted the flipped classroom modality (FCM) for the following reasons: (i) Some evidence that students acquiring competences in STEM achieve better learning outcomes from discussions, demonstrations, and problem-based projects than from formal lectures [100, 31, 87, 97],(ii) acquaintance of students with the study material before class leaves more time during lectures for complementary activities (e.g., cooking demonstrations, discussing videos and listening to invited speakers),(iii) ready access to an experimental kitchen and a staff of chefs and a well-equipped FMS laboratory; and (iv) introduce active learning as a teaching methodology that places the student at the center of the educational process [88].

The extensive review of Karabulut-Ilgu et al. [31] on the practice of the flipped learning approach in engineering education suggests that students exposed to this modality learn as much or more than their counterparts do in a traditional lecture course. Nevertheless, the invoked benefits and effectiveness of flipped classrooms depend on the learning environment, subject domain, and other factors [89].

Table 1 presents a condensed syllabus of the Introduction to gastronomic engineering course, including prerequisites, learning objectives, and the main topics of the lectures. FCM hold students responsible for reviewing in advance all prepared materials (e.g., lecture modules, videos, and articles), so the lecture period becomes a dynamic and interactive learning space [90]. Thus, a set of lecture notes (in English) with 34 thematic sections or modules displayed in 250 pages was prepared during the year 2014. The text highlights concepts of FE and FMS and the relation to basic cooking techniques and dishes. Lecture notes contain around two hundred graphs, schemes, and photographs.

The course, offered for the last five years in the spring semester, fulfills the curricular requirement of an elective undergraduate course in Fundamentals of Science and Engineering. Around 50\% of students have a major in chemical engineering (there in no FE major), and the rest belong to other engineering disciplines (environmental, computer science, mechanical, operations research), and occasionally, chemistry and agronomy majors. An abridged 1 -week version of the course was recently delivered at University of Pretoria (South Africa) to food science and culinary arts students. Figure 3 depicts the sequence of teaching/learning activities of the course. Students have to read two or three sections of the lecture notes before class and their preparedness is evaluated by a $15-\mathrm{min}$, multiple-choice quiz at the beginning of each class. The lecture starts by commenting the reading assignments and the quiz and continues with the presentation of specific FE or FS\&T topics, assisted by 3 to 5 culinary demos by the chefs. Occasionally, students attend demonstrations of the operation of laboratory or pilot plant equipment. Table 2 lists some examples of in-class demonstrations and laboratory observations. Special emphasis during demos is on relating key concepts, equations, and graphs to culinary phenomena. Discussions centered on students' inquiries and chefs' 
Table 1 Condensed syllabus of the course Introduction to Gastronomic Engineering

\begin{tabular}{|c|c|}
\hline IIQ-2930 & Introduction to Gastronomic Engineering \\
\hline Instructors & José M. Aguilera and M. Carolina Moreno \\
\hline Semester & Spring (August to December) \\
\hline Prerequisites & High school chemistry and biology; a course in thermodynamics \\
\hline Credits & 10 (equivalent to $10 \mathrm{~h}$ of work per week) \\
\hline Schedule & Thursdays, modules 5 and $6(15: 30$ to $18: 20)$ \\
\hline Objective & $\begin{array}{l}\text { To present the science and engineering in the kitchen and during cooking, and explain the origin, main transformations and } \\
\text { characteristics of gastronomic structures }\end{array}$ \\
\hline $\begin{array}{l}\text { Learning } \\
\text { outcomes }\end{array}$ & $\begin{array}{l}\text { At the end of this elective course, students will be able to: (i) describe chemical components and structures in some food } \\
\text { recipes; (ii) interpret basic equations and simple diagrams of food physical chemistry and food materials science; (iii) } \\
\text { explain in scientific and engineering terms how culinary techniques work; (iv) relate key scientific concepts to properties } \\
\text { of foods and meals; and (v) practice and use technical written and oral communication skills (term project) }\end{array}$ \\
\hline Topics & $\begin{array}{l}\text { Introduction: on gastronomy and chefs. Molecules in our body and foods } \\
\text { A good look at food (food microstructure); cooking under the microscope } \\
\text { Edible structures from nature and their main transformations } \\
\text { Foods as engineering materials; from crispy to soggy } \\
\text { Heating: energizing molecules; mass transfer: molecules on the move } \\
\text { Gels: chewy water; foams: structures out of thin air } \\
\text { Emulsions: mixing the enemies; milk and dairy nanotechnology } \\
\text { Structuring cereal products: bread, pasta, extrusion; frying } \\
\text { Meat: barbecue at the lab. Experimenting and measuring in the kitchen. } \\
\text { Food aging and senescence; chocolate and blooming } \\
\text { Souffé: an ephemeral structure; delicious desserts (Invited speaker) } \\
\text { Foods inside our bodies; healthy eating (invited speaker) } \\
\text { Chef's choices and creations. Tasting foods by pros (Invited speaker) } \\
\text { Presentations and final wrap-up }\end{array}$ \\
\hline Grading & Quizzes (70\%); the lowest two scores are dropped. Term project (30\%) \\
\hline Text & $\begin{array}{l}\text { Aguilera [21]. Lecture Notes on Gastronomic Engineering (5th version). Internal document only for the use of students } \\
\text { enrolled in the course }\end{array}$ \\
\hline $\begin{array}{l}\text { Recommended } \\
\text { references }\end{array}$ & $\begin{array}{l}\text { McGee H (2004) [102]. On food and cooking: The science and lore of the kitchen (2nd ed.). Scribner, NY } \\
\text { Myhrvold et al. [85] Modernist Cuisine: The Art and Science of Cooking. The Cooking Lab, Bellevue, WA } \\
\text { Vilgis TA (2015) [103] Soft matter food physics—the physics of food and cooking. Reports on Progress in Physics 78:(12) } \\
\text { 124,602 }\end{array}$ \\
\hline
\end{tabular}

experiences are highly encouraged. After class, participants work in small groups in the test kitchen or at home on a problem that encourages autonomous learning through experimentation in the kitchen Kokotsaki [91]. Alternatively, the group may write a review paper on a topic that links gastronomy with the contents of the course. The final report of this term project is a 3-min video or 4-page paper.

\section{Evaluation of the Course}

Learning outcomes were evaluated by quizzes and the term project. Questions in multiple-choice quizzes (8 to 10 per quiz, over 100 during the semester) assessed the understanding of key concepts, facts, and methods described in the assigned reading material. Participation

\begin{tabular}{|c|c|c|c|}
\hline $\begin{array}{l}\text { BEFORE CLASS } \\
\text { Students read and } \\
\text { prepare the assigned } \\
\text { material from lecture } \\
\text { notes. } \\
\qquad \text { (3 to } 4 \mathrm{hrs} \text { ) }\end{array}$ & $\begin{array}{l}\text { AT START OF CLASS } \\
\text { Students take a reading } \\
\text { quiz to evaluate their } \\
\text { preparedness and } \\
\text { understanding. } \\
\qquad(15 \mathrm{~min})\end{array}$ & $\begin{array}{l}\quad \text { DURING CLASS } \\
\text { Lecturer emphasizes key } \\
\text { concepts, presents } \\
\text { examples, promotes } \\
\text { discussion. Chefs } \\
\text { perform demonstrations. } \\
\text { Visits to laboratories. } \\
\text { (2.5 to } 2.8 \mathrm{hr} / \text { week) }\end{array}$ & $\begin{array}{l}\quad \text { AFTER CLASS } \\
\text { Students work in small } \\
\text { groups on a term project } \\
\text { under tutorial } \\
\text { supervisión. Use of } \\
\text { experimental kitchen and } \\
\text { laboratories. } \\
\text { (2 to } 3 \mathrm{hr} / \text { week) }\end{array}$ \\
\hline
\end{tabular}

Fig. 3 Sequence of teaching/learning stages in the flipped-classroom course Introduction to gastronomic engineering 
Table 2 Some examples of in-class demonstrations and laboratory observations in the Gastronomic Engineering course

\begin{tabular}{|c|c|}
\hline Concept & Demonstration/observation \\
\hline \multicolumn{2}{|l|}{ Food engineering } \\
\hline Heat transfer & $\begin{array}{l}\text { Cooking soft eggs in boiling water and in a water bath }\left(65^{\circ} \mathrm{C}\right) \\
\text { Insulating effect of meringue and cake on ice cream during flambéing of Baked Alaska } \\
\text { Transient heat transfer during cooking of pasta al dente }\end{array}$ \\
\hline Mass transfer & $\begin{array}{l}\text { Extraction of solutes from a tea bag in hot water } \\
\text { Soaking and hydration of dry seaweeds } \\
\text { Osmotic dehydration of egg yolks immersed in salt/sugar }\end{array}$ \\
\hline Sedimentation & Creaming of fat globules after mixing oil and water \\
\hline Concentration & Reduction of beef stock in a rotary evaporator \\
\hline Freeze-drying & Start-up of a pilot plant freeze-drier \\
\hline Freezing & Making yogurt ice cream with liquid nitrogen \\
\hline Centrifugation & Clarification of turbid broth in a lab centrifuge \\
\hline Extrusion & Cooking-shaping a starchy flour in a pilot plant extruder \\
\hline Measuring variables & Use of hygrometer, thermocouples, infrared thermometer \\
\hline \multicolumn{2}{|l|}{ Food materials science } \\
\hline Food microstructure & $\begin{array}{l}\text { Black pepper seeds in stereomicroscope and stained onion cells under a light } \\
\text { microscope. Operation of MicroCT and scanning electron microscope }\end{array}$ \\
\hline Mechanical properties & Testing of potato chips in a texture-meter \\
\hline Brittleness & Fracturing of deep-frozen orange segments into juice sacs \\
\hline Gelation & Spherification of alginate beads in a calcium bath \\
\hline Foaming & Whipping of egg white and use of syphon \\
\hline Emulsification & "Vegan mayonnaise" prepared from soy milk and oil \\
\hline Emulsion inversion & Making butter (W/O emulsion) by whisking heavy cream \\
\hline Starch gelatinization & Viscosity increase during heating of a corn starch suspension \\
\hline Crystal/glass transition & Melting of table sugar and spinning into cotton candy \\
\hline Fat melting & Preparation of clarified butter \\
\hline Fat crystallization & Tempering and molding of a bloomed chocolate mass \\
\hline \multicolumn{2}{|l|}{ Physics/physical chemistry } \\
\hline Density & Floating of soft meringue on English cream (Floating islands) \\
\hline Viscosity & Thickening soups and creams with starch and gums \\
\hline Viscoelasticity & Extensibility of gluten (after washing a wheat flour dough) \\
\hline Capillarity & Soaking of liquor by a $b a b a$ (Italian cake dessert) \\
\hline Water sorption & Potato chips exposed to different relative humidity in desiccators \\
\hline Vapor pressure & Expansion of a soufflé in the oven, puffing of Indian bread \\
\hline
\end{tabular}

during the class (e.g., good answers and good questions) received extra points in quizzes. An advanced mid-term and a final presentation of the term project aimed at the use of information tools, articulation of scientific concepts, originality, and ability to communicate the results. Marks in videos and written reports reflected compliance with the respective rubrics handed out to students. The average grade for the course was slightly higher than the average GPA of the group (5.5 and 5.3, respectively, on a scale of 1 to 7 ).

The University evaluates students' satisfaction with courses through a standardized questionnaire accessible online. Responses are optional and the feedback is well below $40 \%$, which is common for undergraduate courses [92]. Pooled available scores ( 4 years, $n=86$ ) of the general attitude of students towards the course (Do you recommend the course to others? and Have you learned according to your expectations?) were above the mean for courses imparted by the School of Engineering Table 3. Eighty-six percent of students were satisfied with the course, and $92 \%$ thought they had learned more or much more than what they expected Table 3. Data suggest that the course in FCM was effective and appreciated.

In 2018, we created an end-of-course evaluation focused on students' attitudes and beliefs towards specific aspects of the course and the FCM [93]. Response data are only available for that year and 2020, since in 2019, the university shut down 4 weeks before the end of the semester due to civil protests in Chile. Table 3 shows that most students (33/37) were neutral to very positive (scores 3,4 , and 5) of the FCM, and none of them rated it with the lowest score (very 
Table 3 Summary of students' evaluation (2018 and 2020) and attitudes towards course Introduction to Gastronomic Engineering (4 years)

\begin{tabular}{llllll}
\hline Item in evaluation & \multicolumn{4}{l}{ Score $(n=37)$} \\
\hline & 1 & 2 & 3 & 4 & 5 \\
1- Appreciation of flipped class modality & 0 & 4 & 9 & 13 & 11 \\
2- Usefulness of lectures notes & 0 & 0 & 7 & 14 & 16 \\
3- Usefulness of demonstrations/videos & 0 & 0 & 4 & 10 & 23 \\
4- Quizzes at beginning of class & 2 & 8 & 7 & 13 & 7 \\
5- Value of term project & 1 & 4 & 9 & 17 & 6 \\
6- Value of the course as elective in science & 0 & 1 & 6 & 12 & 18 \\
7- Application of learned material & 1 & 0 & 6 & 14 & 16 \\
Attitudes & Percentage $(n=86)$ \\
& Yes & \multicolumn{5}{c}{ No } \\
Do you recommend the course to others? & 86 & \multicolumn{5}{c}{14} \\
Have you learned according to expectations? & 91.7 & \multicolumn{7}{c}{8.3} \\
\hline
\end{tabular}

Scale: $1=$ very negative $2=$ negative $3=$ neutral $; 4=$ positive $; 5=$ very positive

negative). The usefulness of lecture notes rated even higher (37/37). Students praised highly in-class demonstrations and laboratory observations (mostly videos from Internet in 2020), and $89 \%$ gave them the top two scores. This suggests that cooking experiments are instrumental to explain and convey the contents of the course and that observations in laboratories may partly replace hands-on experiences [74, 94]. Around $27 \%$ of the students (10/37) disliked the unfamiliar practice of taking reading quizzes at the beginning of the class. However, reading quizzes prepare students for an active in-class work and are an early alert of learning weaknesses [95]. Although most students valued the experience of the term project, some requested clearer instructions of the expectations. The complaint is usual in food science students exposed for the first time to this type of assignments and was improved in 2020 with a detailed rubric for the term project $[40,98]$. A few comments pointed out that lectures were sometimes redundant, a matter that is a common criticism for flipped class courses [93]. No comparison between the FCM and the "traditional approach" (lecture-based course) is available for this elective course. The limited enrollment $(n<35$ students $)$ and costs of running parallel sections under similar conditions (e.g., same semester and staff) hampers carrying out this evaluation.

\section{Conclusions}

Understanding concepts of FE is fundamental for professionals in the discipline, necessary for food scientists, appealing to non-science students, and valuable in the culinary arts and gastronomy. The vibrant FE education of the past oriented to an expanding food manufacturing industry now faces new realities and challenges. The present gloomy scenario for FE education in academia may reflect a disconnection with societal needs as well as inadequate teaching approaches and unattractive ways of delivering the contents. Nevertheless, four main student audiences demand-to different extentsconcepts of FE as part of their curricula: FE and FS\&T majors, other undergraduates seeking STEM electives, and students in culinary arts and gastronomy.

The present scenario necessarily calls for a change in the paradigm of the traditional FE education based on understanding heat, mass, and momentum transfer in unit operations of the food processing industry. Although this will continue as a main focus for FE majors, particularly in reference to emerging technologies, a new vision should deploy these concepts in the context of sustainable food processes, products that address changing lifestyles, and innovations leading to better health and well-being. Product engineering and rational design based on FMS and targeted to specific consumer's needs and wants arises as an option to address the challenges. Such approach requires an interdisciplinary construct of reformulated courses and novel educational methodologies. Meanwhile, ICT has transformed the educational landscape and, as a result, teaching FE should become more dependant on online and open learning platforms. At the same time, in class, lectures must evolve into student-centered and participative environments.

The elective course on gastronomic engineering delivers concepts of FE, FMS, and physics to undergraduates in the context of familiar culinary practices and may satisfy the STEM requirements for non-science students. Customized lecture notes and demonstrations by chefs are fundamental to achieve the objectives of active learning. The FCM leaves ample time to reinforce important concepts, present additional examples, promote students' viewpoints and engagement in a group term project. Alternatively, the FCM and some of the contents, demonstrations, and term project of the GE course may provide a framework for an interdisciplinary course in food product design within the undergraduate FE curriculum. However, the impact of GE courses for FE and non-FE students in the FCM needs further evaluation.

Acknowledgements The authors acknowledge the contribution of chefs Francisco Pedemonte (2015), Maike Siegel (2016-2018) and Axel Palacios (2019) in the preparation and presentation of culinary demonstrations and many graduate students that showed the operation of laboratory equipment. Special thanks to Prof. Helmar Schubert (Karlsruhe Institute of Technology) for information of the emergence of food engineering at that institution.

Funding Financial support from Fondecyt (Fondo Nacional de Desarrollo Científico y Tecnológico, Chile) and specifically grant 1180082 has stimulated research and teaching in our Gastronomic Engineering Unit. 


\section{References}

1. Heldman DR, Lund DB (2011) The beginning, current and future of food engineering: a perspective. In: Barbosa-Cánovas GV, Simpson R, Welti-Chanes J, Bermudez-Aguirre D (eds) Aguilera JM. Food engineering interfaces. Springer, New York (pp, pp 3-8

2. Karel M (1997) The history and future of food engineering. In Fito P, Ortega E, Barbosa GV (eds) Food engineering 2000. Chapman \& Hall, New York (pp 3-19)

3. Kostaropoulos AE (2012) Food engineering within sciences of food. Int J Food Stud 1:109-113

4. Barbosa-Canovas GV, Juliano P (2005) Introduction: food engineering. In: Barbosa-Canovas GV (ed) Food engineering: encyclopedia of life support systems. EOLSS, Paris, pp 1-24

5. Bruin S, Jongen ThRG (2003) Food process engineering: the last 25 years and challenges ahead. Compr Rev Food Sci Food Saf 2:42-81

6. Charm SE (1963a) Fundamentals of food engineering. AVI Publishing, Westport

7. Gekas V (1992) Transport phenomena of foods and biological materials. CRC Press, Boca Raton

8. Singh RP (1992) The current core literature of food engineering. In: Hall CW, Olsen WC (eds) The literature of agricultural engineering. Cornell University Press, Ithaca, pp 117-125

9. Saguy IS, Singh RP, Johnson T, Fryer PJ, Sastry SK (2013) Challenges facing food engineering. J Food Eng 119:332-342

10. Aguilera JM (2018a) Food engineering into the XXI century. AIChE J 64:2-11

11. Niranjan K (2016) A possible reconceptualization of food engineering discipline. Food Bioprod Process 99:78-89

12. Saguy IS, Cohen E (2016) Food engineering: attitudes and future outlook. J Food Eng 171:71-80

13. Barham P (2013) Physics in the kitchen. Flavour 2, 5. https://doi. org/10.1186/2044-7248-2-52044-7248-2-52044-7248-2-520447248-2-5

14. Keast R, Macfarlane S, Riddell L (2012) Effective integration of teaching and research in a first year food and nutrition course. Creat Educ 3:1366-1370

15. Rowat AC, Sinha NN, Sörensen PM, Campàs O, Weitz DA (2014) The kitchen as a physics classroom. Phys Educ 49(5):512-522

16. Aguilera JM (2012) The engineering inside our dishes. Int J Gastron Food Sci 1:31-36

17. Kong F, Singh RP (2008) Disintegration of solid foods in human stomach. J Food Sci 73(5):R67-R80

18. Aguilera JM (2018b) Relating food engineering to cooking and gastronomy. Compr Rev Food Sci Food Saf 17(4):1021-1039

19. Brenner MP, Sorensen PM (2015) Biophysics of molecular gastronomy. Cell 161:5-8

20. Swinbank E, Parker K (2004) Foods inspire teaching of physics. Phys Edu 39(1):5-7

21. Aguilera JM (2020) The concept of alimentation and transdisciplinary research. J Sci Food Agric. https://doi.org/10.1002/jsfa.10823

22. Boom RM, Janssen AEM (2014) Food Engineering. In: Van Alfen NK (ed) Encyclopedia of agriculture and food systems. Elsevier, Amsterdam, pp 154-166

23. Roos YH, Fryer PJ, Knorr D, Schuchmann HP, Schroën K, Schutyser MAI, Windhab EJ (2015) Food engineering at multiple scales: case studies, challenges and the future - a European perspective. Food Eng Rev 8(2):91-115

24. Fedoroff NV, Battisti DS, Beachy RN, Cooper PJ, Reynolds MP (2010) Radically rethinking agriculture for the 21st century. Science 327(5967):833-834

25. Knorr D, Watzke H (2019) Food processing at a crossroad. Front Nutr 6. https://doi.org/10.3389/fnut.2019.000852019.000852019. 000852019.00085
26. Raats M, De Groot L, van Asselt D (2016) Food for the aging population, 2nd edn. Woodhead, Amsterdam

27. Hernández-de-Menéndez M, Vallejo Guevara A, Tudón Martínez JC et al (2019) Active learning in engineering education. A review of fundamentals, best practices and experiences. Int J Interact Des Manuf 13:909-922

28. García-Peñalvo FJ, Colomo-Palacios R (2015) Innovative teaching methods in engineering. Int J Eng Educ 31(3):689-693

29. Dym CL, Agogino AM, Eris O, Frey DD, Leifer LJ (2005) Engineering design thinking, teaching, and learning. J Eng Educ 94(1):103-120

30. Jamison A, Kolmos A, Holgaard JE (2014) Hybrid learning: an integrative approach to engineering education. J Eng Educ 103(2):253-273

31. Karabulut-Ilgu A, Jaramillo-Cherrez N, Jahren CT (2017) A systematic review of research on the flipped learning method in engineering education. Br J Educ Technol 49(3):398-411

32. Medina FX, Pinto de Moura A, Vázquez-Medina JA, Aguilar A (2019) Feeding the online: perspectives on food, nutrition and the online higher education. Int J Educ Technol High Educ 16:42. https://doi.org/10.1186/s41239-019-0173-y

33. Ali W (2020) Online and remote learning in higher education institutes: a necessity in light of Covid-19 pandemic. High Educ Stu 10: 3 https://doi.org/10.5539/hes.v10n3p16

34. Bimbenet J-J, Schubert H, Trystram G (2007) Advances in research in food process engineering as presented at ICEF 9. J Food Eng 78(2):390-404

35. Barron FH (2019) The food engineer. In: Kutz M (ed) Handbook of farm, dairy and food machinery engineering, 3rd edn. Academic Press, London, pp 1-13

36. Flynn K, Wahnström E, Popa M, Ruiz-Bejarano QMAC (2013) Ideal skills for European food scientists and technologists: identifying the most desired knowledge, skills and competencies. Innov Food Sci Emerg Technol 18:246-255

37. Welti-Chanes J, Vergara-Balderas F, Palou E, Alzamora S, Aguilera JM, Parada E (2002) Food engineering education in Mexico, Central and South America. J Food Sci Educ 1:59-65

38. Silva VL, Makishi F, Magossi M, Freitas IC, Favaro CS, Sobral PJ (2018) Are we doing our homework? An analysis of food engineering education in Brazil. Int J Food Stud 7:1-16

39. Hayoglu I, Celik S, Artık N, Atasoy A (2016) Engineering education and current situation of food engineering education in Turkey. FEIIC IJET 13(1):1-4

40. Bosman L, Eom S (2019) Using scaffold innovation-thinking frameworks to integrate food science and technology into the transdisciplinary engineering design classroom. Int J Educ Technol High Educ 16:35. https://doi.org/10.1186/s41239-019-0165-y

41. Cohen N (2010) Designing the sustainable foodshed: a crossdisciplinary undergraduate environmental studies course. Innov High Educ 35:51-60

42. Saguy IS, Roos YH, Cohen E (2018) Food engineering and food science and technology: forward-looking journey to future new horizons. Innov Food Sci Emerg Technol 47:326-334

43. ABET (2019) Criteria for accrediting engineering programs, 2020-2021. Retrieved from https://www.abet.org/accreditation/ accreditation-criteria/criteria-for-accrediting-engineeringprograms-2020-2021/

44. Parker ME, Harvey EH, Stateler ES (1952) Elements of food engineering (3 volumes). Reinhold Publishing Corporation, New York

45. McNulty P (2003) Food engineering. In Lalor B (ed) The Encyclopedia of Ireland. Gill and Macmillan, Dublin (p. 409)

46. Plank R (1941) Beitrage zur Berechnung und Bewertung der Gefriergeschwindigkeit van Lebensmitteln. Beiheft $Z$ ges Kaltelnd 3(10):1-16 
47. Loncin M (1969) Die Grundlagen der Verfahrenstechnik in der Lebensmittelindustrie Aarau, Frankfurt

48. Loncin M, Merson RL (1979) Food engineering. Academic Press, New York, Principles and Selected Applications

49. Goldblith SA (1995) On microbes and molecules. Food Technology, Nutrition and Applied Biology at M.I.T. 1873-1988. Food and Nutrition Press, Trumbull, USA

50. Charm SE (1963b) The nature and role of fluid consistency in food engineering applications. Adv Food Res 11:355-435

51. Roos YH, Saguy IS (2020) In memoriam: Professor Emeritus Marcus (Marc) Karel (1928-2019): a food science and food engineering pioneer, exceptional educator, mentor, and friend. J Food Sci Educ 19(2):32-35

52. Karel M, Lund DB (2003) Physical principles of food preservation, 2nd edn. Marcel Dekker, New York

53. Singh RP, Heldman DR (1984) Introduction to food engineering. Academic Press, Orlando FL

54. Dumoulin E (2006) Trends in food science education in Europe. J Food Sci 69(3):CRH98-CRH99

55. Vieira M, Ho P (2008) Experiments in unit operations and processing of foods. Springer, New York

56. Clark JP (2012) Good practices for pilot plants. Food Technol 66(9):1-4. https://www.ift.org/news-and-publications/foodtechnology-magaz ine/issue s/2012/septe mber/columns/ processing2012/september/columns/processing

57. Young BR, Yarranton HW, Bellehumeur CT, Svrcek WY (2006) An experimental design approach to chemical engineering unit operations laboratories. Trans Inst Chem Eng (Part D) 1(1):16-22

58. Koretsky MD, Magana AJ (2019) Using technology to enhance learning and engagement in engineering. Adv Eng Educ June 2019. Retrieved from https://advances.asee.org/using-technologyto-enhance-learning-and-engagement-in-engineering/

59. Normand MD, Lesmes U, Corradini MG, Peleg M (2010) Wolfram demonstrations: free interactive software for food engineering education and practice. Food Eng Rev 2(3):157-167

60. Datta AK, Ukidwe MS, Way DG (2020) Simulation-based enhancement of learning: the case of food safety. J Food Sci Educ 19(3):192-211

61. Datta AK (2016) Toward computer-aided food engineering: mechanistic frameworks for evolution of product, quality and safety during processing. J Food Eng 176:9-27

62. Moggridge GD, Cussler EL (2000) An introduction to chemical product design. Chem Eng Res Des 78(1):5-11

63. Aguilera JM, Lillford PJ (2008) Food materials science: principles and practice. Springer, New York

64. Bhandari B, Roos Y (2012) Food materials science and engineering. Blackwell Publ, Oxford

65. Slade L, Levine H (1991) Beyond water activity: recent advances based on an alternative approach to the assessment of food quality and safety. Crit Rev Food Sci Nutr 30(2-3):115-360

66. Zhang L, Fung K, Wibowo C, Gani R (2018) Advances in chemical product design. Rev Chem Eng 34(3):319-340

67. Costa R, Mozina SS, Pittia P (2014) The regulation of food science and technology professions in Europe. Int J Food Stud 3(1):125-135

68. Misra NN, Koubaa M, Roohinejad S, Juliano P, Alpas H, Inácio RS, Barba FJ (2017) Landmarks in the historical development of twenty first century food processing technologies. Food Res Int 97:318-339

69. IFT (2019) 2018 Guidelines for initial IFT approval of undergraduate food science and food technology programs. Institute of Food Technologists, Chicago

70. Singh RP, Heldman D (2009) Introduction to food engineering, 4th edn. Academic Press, New York

71. Hartel RW (2009) Foreword. In Singh RP, Heldman, DR Introduction to food engineering, Academic Press, New York (p. VII)
72. Adedeji AA (2019) Challenges and discovery of best practices for teaching food engineering to food science majors - my experience over my first 5 years at the University of Kentucky. $\mathbf{J}$ Food Sci Educ 19:7-9

73. Singh RP (2020) www.rpaulsingh.com/course/

74. Miles DT, Bachman JK (2009) Science of food and cooking: a non-science majors course. J Chem Educ 86:311-315

75. Van der Linden E (2013) Integration of gastronomy and physics for innovation. Flavour 2:11. https://doi.org/10.1186/20447248-2-112044-7248-2-11

76. Rowat AC (2013) The molecules we eat: food as a medium to communicate science. Flavour 3:10. https://doi.org/10.1186/20447248-2-102044-7248-2-10

77. Aguilera JM (2017) The emergence of gastronomic engineering. Innov Food Sci Emerg Technol 41:277-283

78. Merrill C, Lawler M (2019) Integration of science, technology, engineering, and math into a food and nutrition curriculum in Utah. Fam Consum Sci Res J. https://doi.org/10.1111/fcsr.12326

79. Wang H, Knobloch NA (2018) Levels of STEM integration through agriculture, food, and natural resources. J Agr Educ 59(3):258-277

80. Radchenko A, Dyukareva G, Afanasyeva T, Kornitskaya A, Yakubyan S, Karapandzha A (2020) Competency-based approach in higher education: competency-based model of the engineer for the food industry. ScienceRise 3:58-65

81. Christensen M, Stuart RE (2019) Teaching science to chefs: the benefits, challenges and opportunities. Int J Gastron Food Sci. https://doi. org/10.1016/j.ijgfs.2019.01.0012019.01.001

82. Cheng M, Ogbeide GA, Hamouz FL (2011) The development of culinary arts and food science into a new academic discipline. J Culin Sci Technol 9:17-26

83. Rodgers S (2009) The state of technological sophistication and the need for new specialised tertiary degrees in food services. Int J Hosp Manag 28:71-77

84. Rega B, Moussa M, Laissy I, Mian C, Burke R, Vitaglione P. (2018) Training of a new generation of talents capable of working across borders and sectors, with an inclusive approach of food innovation: the case of FIPDes, the ERASMUS Mundus Joint Master's Degree in Food Innovation and Product Design. Proceedings from the 5th International ISEKI_Food Conference. University of Hohenheim, 3-5 July, Stuttgart, Germany

85. Myhrvold N, Young C, Bilet M (2011) Modernist cuisine: the art and science of cooking. The Cooking Lab, Bellevue, WA

86. Adria F (2009) Modern gastronomy: A to Z. CRC Press, Boca Raton

87. González-Gómez D, Jeong JS, Airado D, Cañada-Cañada F (2016) Performance and perception in the flipped learning model: an initial approach to evaluate the effectiveness of a new teaching methodology in a general science classroom. J Sci Educ Technol 25(3):450-459

88. Esteve F (2016) Bolonia y las TIC: De la docencia 1.0 al aprendizaje 2.0. Cuest Univ 5:58-67

89. DeLozier SJ, Rhodes MG (2017) Flipped classrooms: a review of key ideas and recommendations for practice. Educ Psychol Rev 29:141-151

90. Uzunboylu H, Karagozlu D (2015) Flipped classroom: a review of recent literature. WJET 7(2):142-147

91. Kokotsaki D, Menzies V, Wiggins A (2016) Project-based learning: a review of the literature. Improv Sch 19(3):267-277

92. Guder F, Malliaris M (2013) Online course evaluations response rates. Am J Bus Educ 6(3):333-337

93. Sterner EO, Svensson OH, Toivonen S, Bill J, Adawi T (2017) Evaluating the flipped classroom approach in engineering education: students' attitudes, engagement and performance in an undergraduate sustainability course. Paper presented at the 45th Annual Conference of the European Society for Engineering Education, 18-21 September 2017, Azores, Portugal 
94. McKee E, Williamson VM, Ruebush LE (2007) Effects of a demonstration laboratory on student learning J Sci Educ Tech 16(5):395-400

95. Hodges LC, Anderson EC, Carpenter TS, Cui L, Wagner CR (2015) Using reading quizzes in STEM classes - the what, why, and how. J Coll Sci Teach 1:49-55

96. Aguilera JM, Stanley DW (1989) Microstructural principles of food processing and engineering. Elsevier, London

97. Crouch CH, Fagen AP, Callan JP, Mazur E (2004) Classroom demonstrations: learning tools or entertainment? Am J Phys 72(6):835-838

98. Duffrin MW (2003) Integrating problem-based learning in an introductory college food science course. J Food Sci Educ 2:1-6

99. Otto KN, Wood KL (1998) Product evolution: a reverse engineering and redesign methodology. Res Eng Des 10(4):226-243
100. Schwarzenberg P, Navon J, Nussbaum M, Pérez-Sanagustín M, Caballero D (2018) Learning experience assessment of flipped courses. J Comput High Educ 30(2):237-258

101. Wong SY, Connelly RK, Hartel RW (2010) Enhancing student learning in food engineering using computational fluid dynamics simulations. J Food Sci Educ 9(4):90-97

102. McGee H (2004) On food and cooking: The science and lore of the kitchen (2nd ed.). Scribner, NY

103. Vilgis TA (2015) Soft matter food physics - the physics of food and cooking. Reports on Progress in Physics 78:(12) 124602

Publisher's Note Springer Nature remains neutral with regard to jurisdictional claims in published maps and institutional affiliations. 